
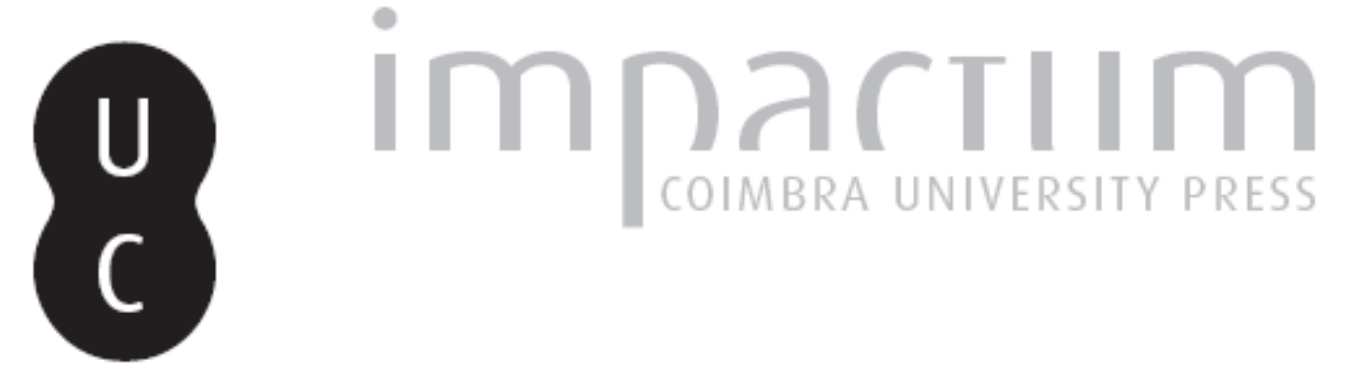

\title{
As manifestações regionalistas em Portugal durante a I República e no início do Estado Novo: (1910-1939)
}

\author{
Autor(es): $\quad$ Amaro, António Rafael
}

Publicado por: Imprensa da Universidade de Coimbra

URL persistente:

URI:http://hdl.handle.net/10316.2/45009

DOI:

DOI:https://doi.org/10.14195/0870-4147_38_14

Accessed : $\quad$ 26-Apr-2023 14:25:42

A navegação consulta e descarregamento dos títulos inseridos nas Bibliotecas Digitais UC Digitalis, UC Pombalina e UC Impactum, pressupõem a aceitação plena e sem reservas dos Termos e Condições de Uso destas Bibliotecas Digitais, disponíveis em https://digitalis.uc.pt/pt-pt/termos.

Conforme exposto nos referidos Termos e Condições de Uso, o descarregamento de títulos de acesso restrito requer uma licença válida de autorização devendo o utilizador aceder ao(s) documento(s) a partir de um endereço de IP da instituição detentora da supramencionada licença.

Ao utilizador é apenas permitido o descarregamento para uso pessoal, pelo que o emprego do(s) título(s) descarregado(s) para outro fim, designadamente comercial, carece de autorização do respetivo autor ou editor da obra.

Na medida em que todas as obras da UC Digitalis se encontram protegidas pelo Código do Direito de Autor e Direitos Conexos e demais legislação aplicável, toda a cópia, parcial ou total, deste documento, nos casos em que é legalmente admitida, deverá conter ou fazer-se acompanhar por este aviso.

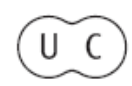



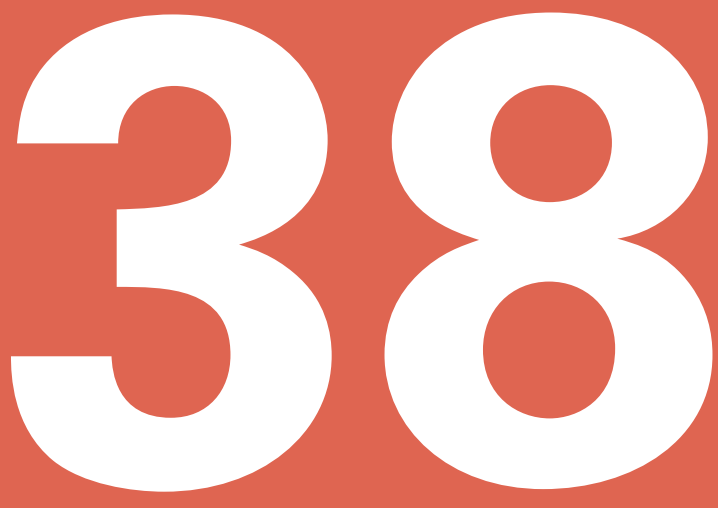

\section{Revista Portuguesa de História}

Faculdade de Letras da Universidade de Coimbra Instituto de História Económica e Social

Coimbra 08 
Revista Portuguesa de História

t. XXXVIII (2006)

pp. $399-418$

\title{
As manifestações regionalistas em Portugal durante a I República e no início do Estado Novo (1910-1939)*
}

\author{
António Rafael Amaro \\ Professor Auxiliar do Centro Regional das Beiras \\ da Universidade Católica Portuguesa \\ Investigador do CEIS20
}

\section{Introdução}

O crescimento, nos últimos anos, de uma maior sensibilidade para os problemas regionais e locais, no quadro de uma sociedade cada vez mais globalizada, tem vindo a contribuir para que as próprias ciências sociais assumam uma visão territorializada nas suas análises, deixando aos poucos de ver a periferia pelos olhos institucionais do centro. Com esta nova abordagem, são agora mais ricas as perspectivas de conhecimento das identidades territoriais, passou a existir uma melhor compreensão das relações entre o poder central e os diferentes poderes periféricos e passaram a ganhar maior relevância os estudos sobre as realidades regionais e locais. Contudo, não obstante os importantes contributos conseguidos nos últimos anos, continuam, infelizmente, a faltar estudos de conjunto que nos permitam, por exemplo, ter uma visão completa das reacções

* Este artigo é o resultado, com pequenas alterações, de uma conferência na Faculdade de Letras da Universidade de Coimbra, em 7/12/04, a convite do Instituto de História Económica e Social. Agradeço ao Doutor João Paulo Avelãs Nunes o incentivo para a sua concretização em artigo. 
regionais e locais sobre as transformações económicas, sociais e políticas ligadas às sociedades modernas.

$\mathrm{O}$ estudo do movimento regionalista que aqui pretendemos fazer inscreve-se precisamente nesta tentativa de melhor percebermos o significado de um conjunto de movimentações sociais que, durante a I República e os primeiros tempos do Estado Novo, reivindicavam junto do poder central uma outra forma de organização administrativa do país, mais descentralizada, bem como uma maior atenção aos problemas regionais e locais.

\section{O Regionalismo e os Congressos Regionais como assembleias magnas da Província}

A vertente mais visível do movimento regionalista em Portugal, durante a I República e as duas primeiras décadas do Estado Novo, passou pela organização de congressos regionais em diferentes capitais de distrito. Nestes encontros, para além do proselitismo regionalista e do carregado simbolismo identitário em favor das respectivas Províncias, eram também feitas propostas concretas ao poder central de desenvolvimento que, invariavelmente, visavam combater o esquecimento e o atraso do mundo rural. Aliás, a ideia de combater o esquecimento a que eram votadas as Províncias fazia parte integrante do discurso de mobilização dos líderes do movimento e esta leitura da realidade esteve sempre no centro dos objectivos dos principais promotores dos congressos regionais. Refira-se, no entanto, que estas reuniões magnas provinciais estão longe de ser uma originalidade portuguesa ${ }^{1}$. Também em França, logo nos finais do século XIX, as manifestações regionalistas tiveram como areópagos privilegiados a organização de congressos ${ }^{2}$. Por isso, quando em 1913 o jornal $O$ Século lançou na sociedade portuguesa um campanha denominada «Iniciativas do Século: os Congressos regionais», mais não fez, afinal, do que integrar-se numa corrente regionalista que também despontava em vários países europeus. Era, no fundo, um movimento de reacção da Província, muitas vezes sentimental

1 Em 1900, foi criada em Paris a Federação Regionalista Francesa. Ver, neste sentido, NGUYEN (1977: 243).

2 AA.VV. (1977). Ainda que em Portugal o movimento regionalista não tivesse tido a dimensão e a importância atingida noutros países europeus (Espanha, França, Itália), refira-se, no entanto, a coincidência de ter sido também no ano de 1913 que a campanha em prol do regionalismo em França teve um dos seus pontos mais altos, com a organização de um importante congresso regional na cidade de Toulouse. 
e nostálgico, às transformações ocorridas, sobretudo através da progressiva industrialização e urbanização das sociedades ${ }^{3}$.

No quadro das especificidades políticas e económicas da sociedade portuguesa, o regionalismo foi, desde o início, um movimento marcado por um carácter suprapartidário que, no quadro da I República, significava também uma forma de contestação ao domínio do principal partido republicano. É, aliás, neste contexto político que devem ser entendidos os textos do jornal $O$ Século de apoio à organização dos congressos regionais, nomeadamente quando nele se escreve que «a política - na acepção vulgar do termo - absorvia demasiadamente as atenções». Situação pouco compreensível, afirmava-se no mesmo periódico, «quando o problema do regime estava resolvido e agora se impunha cuidar simultaneamente das demais necessidades da nação» ${ }^{4}$. Por isso, «ao Século pareceu que, sem colidir com a obra dos partidos políticos, se poderia intentar a coordenação de tantas e boas vontades, hoje dispersas, no sentido de se auxiliar a tarefa enorme da reconstituição da pátria portuguesa». E esse contributo ia no sentido de, através das páginas do jornal, «fixar o que cada região necessita e, com o concurso das energias locais», levar à organização de «congressos regionais, os quais deveriam funcionar nas sedes dos distritos administrativos $\rangle^{5}$.

Esta iniciativa do jornal $O$ Século teve uma adesão significativa em todo o país e, muito em especial, nos distritos mais periféricos ${ }^{6}$. Tendo em conta os comentários que, na altura, vários líderes regionais e responsáveis políticos fizeram, é possível fazer uma ideia do modo como a campanha foi recebida. Assim, em 18 de Abril de 1913, A Liga Alentejana - foi uma das primeiras estruturas regionalistas fundadas no Continente, após a proclamação da I República $(1912)^{7}$ - esteve entre as primeiras associações a manifestar o seu apoio. Alguns dias mais tarde, o deputado Carlos Araújo, eleito por Trás-os-Montes, afirmava em entrevista ao mesmo jornal que «a iniciativa do século organizando em todos os distritos os congressos regionais, merecia o aplauso

3 Recorde-se, como exemplo, que, já em Janeiro de 1912, o jornal A Capital lançou um inquérito sobre «O que a Província pensa e o que a Província precisa».

4 TORREJON (1973: 275 e nota 13).

5 O Século, de 15 de Abril de 1913.

6 O jornal $O$ Século acompanhou esta ideia de promover congressos regionais com entrevistas a deputados, governadores civis, membros do governo e elites locais, procurando saber o que pensavam desta iniciativa.

7 A liga Alentejana foi fundada, em 30 de Outubro de 1912, por um grupo de líderes com ligações regionais e locais e com opções políticas diversas, incluindo monárquicos, republicanos, e até o libertário Emílio Costa. Veja-se, neste sentido, VENTURA (2001) e CATROGA (2005: 179). 
de todos quantos se interessam pelo desenvolvimento deste país e dela poderão advir benefícios importantíssimos para a economia nacional, despertando energias adormecidas ${ }^{8}$. Foram também publicadas, entre o mês de Abril e Julho, entrevistas de apoio, sobre o mesmo assunto, do Ministro do Fomento, António Maria Pereira (3 de Junho); do Ministro da Marinha, Feitas Ribeiro (4 de Junho); do Governador Civil de Vila Real (5 de Junho); do governador de Coimbra (11 de Junho); do Director Geral de Agricultura, Câmara Pestana (15 de Junho), do Governador Civil de Évora (16 de Junho); do Director Geral do Comércio e Indústria (24 de Junho); do governador civil de Lisboa, recomendando que os congressos se fizessem por Províncias e não por distritos (26 de Junho) e do Governador Civil de Faro (27 de Junho) 9 .

$\mathrm{Na}$ Beira, destaque-se o teor da entrevista do então deputado eleito pelo círculo da Guarda, António Fonseca, ao considerar que os congressos regionais eram de «extrema necessidade, como indicação feita pelos diversos elementos, sem distinção de cor política, que na província anseiam pelo aproveitamento das forças naturais do nosso solo, organizando-se a valer a nossa agricultura e a nossa indústria que perecem a míngua de uma protecção eficaz $\rangle^{10}$. Também em Viseu a ideia foi muito bem recebida, se tivermos em conta a opinião divulgada pelo periódico monárquico, O Comércio de Viseu: «está a criar raízes a ideia dos congressos regionais, lançada pelo Século, estando a ser apoiada pelos homens mais eminentes do país». Na opinião do articulista, estes congressos deveriam ser o mais possível «suprapartidários, cabendo-lhe apenas servir os interesses da vida colectiva, sob as múltiplas formas que reveste, olhando sob o alevantado (sic) critério regionalista todos os assuntos que à sua discussão viessem. [...] O congresso seria uma espécie de pequeno parlamento dentro do qual outra aspiração se não agitaria, que não fosse a de melhorar e assim solucionar todas as dificuldades em que a vida de cada região actualmente se debate ${ }^{11}$.

Não obstante o bom acolhimento que a iniciativa do jornal $O$ Século teve um pouco por todo o país, pode dizer-se que o movimento regionalista só ressurgiu com vigor na década de 1920 e, em especial, nas províncias menos desenvolvidas. Antes da data referida, apenas se realizou um congresso regional provincial no Algarve (1915), tendo ocorrido a organização dos restantes em anos ulteriores: Trás-os-Montes (1920), Estremadura (1923) e Ribatejo (1923), Minho (1928), Alentejo (1933) e, sobretudo, na Beira. Nesta última Província

\footnotetext{
O Século, 25 de Abril de 1913.

9 O Século (meses de Abril a Julho de 1913).

${ }^{10}$ O Século, de 29 de Junho de 1913.

${ }^{11}$ O Comércio de Viseu, de 1 de Junho de 1913.
} 
realizaram-se, entre 1921 e 1940, nada menos que sete congressos regionais: Viseu 2, em 1921 e 1940; Coimbra 2, em1922 e 1936; Aveiro 1, em 1928; Castelo Branco 1, em 1929; Figueira da Foz 1, em 1932. Dos cinco distritos que compunham a denominada «Beira Histórica» - Aveiro, Castelo Branco, Coimbra, Guarda e Viseu -, apenas a cidade da Guarda recusou, no período considerado (por discordar com a divisão da Beira em Províncias), a organização de qualquer congresso ${ }^{12}$.

Os congressos regionais foram, assim, os palcos por excelência das manifestações regionalistas. E, desde logo, partindo do princípio que as regiões são, em grande medida, o produto de um intenso trabalho ideológico ${ }^{13}$, a decisão de organizar os congressos como uma reunião de toda a Província representou, por si só, uma opção política e simbólica muito importante. Por um lado, esta decisão simbolizava a recusa de todo um legado político de centralização assente na divisão administrativa distrital e, por outro, pretendia-se, também, a (re)construção das antigas identidades provinciais, espaços ligados a uma autonomia local supostamente perdida. Apesar disso, estes eventos estiveram longe de arrastar multidões. Com a excepção de algum folclore de rua exposições de produtos regionais, visitas a certas regiões mais carismáticas, assistir à partida e chegada dos membros do governo - os congressos passaram ao lado da grande massa da população, não indo além do círculo muito restrito das denominadas elites regionais ${ }^{14}$. Ainda assim, pode dizer-se que estas manifestações - por norma demoravam entre 4 e 5 dias - mobilizaram o que de melhor havia entre as elites locais e regionais, beneficiando mesmo de uma certa simpatia por parte da imprensa regional e nacional.

${ }^{12}$ Sobre a querela aberta no distrito da Guarda, quando da divisão administrativa em Províncias, AMARO (2006: 396- 400) e, numa perspectiva mais global, CATROGA (2005: 171-242).

${ }^{13}$ Veja-se, a este respeito, MENDES (1996: 129). De acordo com este autor, «o regionalismo é uma construção identitária, um processo contínuo de simbolização de um território. Consequentemente, as regiões são produto de um trabalho ideológico...».

${ }^{14}$ No congresso realizado em Viseu, entre 9 e 14 de Junho de 1921, só os representantes de instituições e associações - Câmaras Municipais, Sindicatos agrícolas, Associações de Comércio e Indústria, Juntas Gerais de Distrito, jornalistas e deputados eleitos pelos distritos pertencentes à Beira - é que não pagavam qualquer taxa de inscrição. Todas as outras pessoas teriam que pagar $5 \$ 00$ de inscrição, o que, convenhamos, não era muito convidativo para o cidadão comum. 
Com grande aceitação entre os sectores mais conservadores e de oposição ao regime (monárquicos ${ }^{15}$, católicos ${ }^{16}$ e integralistas ${ }^{17}$ ), o regionalismo mereceu também a simpatia e o empenhamento do governo e das elites locais ligadas aos partidos republicanos ${ }^{18}$. Registe-se, por exemplo, a disponibilidade manifestada pelo jornal de Viseu, A Voz da Verdade, afecto ao Partido Democrático, ao apelar, por várias vezes, a todos os beirões para que se unissem em torno da organização do I Congresso Regional das Beiras: «arredemos os ódios, os preconceitos, as políticas daninhas, os egoísmos baixos, os despeitos vis. Mais alto que todos está a ideia da nossa terra» ${ }^{19}$.

Por sua vez, no periódico Notícias de Viseu - tido por órgão oficial do Partido Liberal no distrito -, o discurso não era muito diferente. Apelava-se à participação de todos, dado que «nos trabalhos e na direcção do Congresso não havia política de qualquer espécie» ${ }^{20}$. Ou, melhor, só havia a «política do progresso e engrandecimento da Beira $\rangle^{21}$. Quanto à importância destes eventos para a

${ }^{15}$ Quando da realização do I Congresso Regional das Beiras, em Viseu, não obstante algumas hesitações iniciais, o influente bissemanário monárquico, O Comércio de Viseu, esteve na linha da frente no apoio a esta importante manifestação regional. Alguns meses antes da realização do congresso, em 17 de Fevereiro de 1921, os monárquicos de Viseu davam a sua opinião sobre os objectivos a perseguir por estas manifestações regionalistas: «a missão dos congressos regionais consiste em levantar todas as forças naturais do país, não quase só com obras festivas, espectaculosas, aferventadas em poucos meses, mas com ponderação [...], mais por homens de metier do que por pessoas de valor literário ou político simplesmente». Veja-se O Comércio de Viseu, de 17 de Fevereiro de 1921.

${ }^{16} \mathrm{Em}$ todos os Congressos Regionais, estiveram presentes os representantes da Igreja, nomeadamente os Bispos das respectivas Dioceses, usando da palavra e dando o seu apoio, como aconteceu em Viseu e em Coimbra, por exemplo, para apenas nos referirmos aos congressos realizados antes da instituição da Ditadura Militar.

${ }^{17}$ No caso das Beiras, são evidentes as influências no movimento regionalista das ideias integralistas, com a participação activa mesmo de alguns dos seus mais destacados dirigentes, como foi o caso de Rolão Preto. Este fundador do Integralismo Lusitano e, em 1932, do Nacional Sindicalismo, participou activamente no IV Congresso Regional, realizado em Castelo Branco (1929), com uma tese subordinada ao tema «A Reforma do Estado e a Descentralização Administrativa», em que exigia a reforma urgente e moderna do Estado: descentralização, corporativismo e municipalismo. Identificando-se com Maurice Barrés, este integralista defendia: «ao município os interesses municipais; à região os interesses regionais; à nação os interesses nacionais»». Veja-se IV Congresso Regional das Beiras, 1931: 300-307).

${ }_{18}^{18}$ Cf. LEAL (dir.) (2001), Catroga (2005: 186-190).

19 Voz da Verdade, de 15 de Maio de 1921.

${ }^{20}$ Retenha-se que este discurso pretendia justificar o facto de o Secretário local do Congresso, Dr. Júlio César pertencer ao Partido Liberal, então maioritário na Assembleia.

${ }^{21}$ Veja-se Notícias de Viseu, de 8 de Maio de 1921. Como curiosidade, registe-se que na mesma edição deste jornal foi publicado um entusiasmado apelo «Ao Povo das Beiras», por Aquilino Ribeiro, já então considerado como um «superior espírito» da Beira. O escritor 
região, os articulistas deste mesmo periódico também não pareciam ter dúvidas: os congressos eram importantes «sobretudo por fazer ver aos governos e a todos os que entendem que o país está no Terreiro do Paço que para se governar com o país é preciso fazê-lo de harmonia com as aspirações do povo. E essas não tinham melhor forma de se traduzir e expressar do que nestes prélios onde a voz dos que trabalham e produzem podem levantar-se franca e rudemente para dizer o que sente e o que quer» ${ }^{22}$.

Em 1933, Amorim Girão parecia acreditar que o regionalismo, além da vertente reactiva e sentimental de amor ao torrão natal, revelava uma dimensão nova. Era, no seu entender, o reflexo de um país que, «farto de apelar em vão para o Estado-Providência» (sic), fazia agora apelo às suas próprias forças, aproveitando da melhor forma os recursos que tinha. Era Portugal a tomar consciência de que representava mais alguma coisa do que Lisboa, impedindo que a capital continuasse «a exercer a atracção exagerada que vinha exercendo sobre todas as inteligências, actividades e interesses das populações provinciais» ${ }^{23}$.

Uma visão mais objectiva, sobre o movimento regionalista e a forma como eram organizados os congressos regionais, está longe de confirmar a leitura feita por Amorim Girão - o regionalismo como um movimento com uma dinâmica social que partia da periferia para o centro. Pelo contrário, o regionalismo manifestado nos congressos regionais esteve sempre prisioneiro de vícios antigos e nunca se cansou de apelar para o poder central de quem, supostamente, se pretendia libertar. Quem melhor entendeu esta contradição do regionalismo foi, sem dúvida, Manuel Pires Bento, um dos mais lúcidos representantes deste movimento na Beira: «os soldados desta nova cruzada deveriam declarar a guerra ao existente, inserindo no seu programa a abolição pura e simples dos órgãos da governação pública ou, quando menos, deveriam preconizar reformas destinadas a corrigir os defeitos de que esses organismos enfermam» ${ }^{24}$. E o

apelava às «nobres cidades da Beira, vilas dos cinco distritos, aldeias beiroas das serras e da planície», para que participassem no congresso: «deixai os livros, ponde de lado os negócios, largai da mão o arado e vinde todos a Viseu. [...] No congresso o vosso dever é engrandecer a vossa Beira, pois que a sua grandeza se vai reflectir na herança que legardes aos vossos filhos. Se este é o vosso dever, lavradores trazei os produtos das vossas culturas, os vossos vinhos, os vossos gados, os vossos frutos; industriais apresentai o mostruário das vossas indústrias, das vossas alfaias, das vossas faianças». E o autor do livro Quando os Lobos Uivam, profundo conhecedor dos sentimentos das gentes da Beira, terminava o discurso mobilizador, acrescentando: «pelo renascimento da velha província, pela responsabilidade portuguesa [...] Beirões, ergamo-nos em fé e boa vontade - todos por um, um por todos».

${ }^{22}$ Notícias de Viseu, de 29 de Maio de 1921.

${ }^{23}$ GIRÃO (1933: 3-4).

${ }^{24}$ Veja-se BENTO (1929: 8-9). 
mesmo autor, tentando inverter o rumo que o movimento regionalista tomava, escrevia no periódico Acção Regional ${ }^{25}$, em 1926: «defendemos um processo novo de regionalismo que não passa (este é o velho) por pedir melhoramentos aos governos. [...] Ao Estado não se pedem favores porque o Estado não pode fazer favores sem cometer injustiças. As necessidades locais, as necessidades próprias da região é a região que por si mesma deve procurar satisfazê-las. Ao Estado só se reclamam serviços de interesse geral. Este é o regionalismo que nós defendemos, é o regionalismo que enobrece a região, engrandecendo-a perante o Estado» ${ }^{26}$.

De facto, a metodologia seguida nos congressos regionais fazia depender o desenvolvimento económico da actuação da Administração Central, subalternizando os efeitos que uma mobilização dos potenciais endógenos (administrativos, materiais e humanos) poderiam ter sobre a região. E assim, como lamentavam os defensores da autonomia do poder local, nos congressos em vez de se exigirem reformas administrativas capazes de garantir aos municípios e às regiões meios que garantissem a possibilidade de afirmação de poderes intermédios com capacidade para resolver os problemas, convidavam-se os governantes para tomarem nota deles. Ora, esta postura do movimento regionalista - advertia, mais uma vez, Manuel Pires Bento - tinha o seguinte efeito: «os congressos regionais para estudar os problemas contavam consigo próprios», para os resolver «recorriam aos governos, não dispensando [sequer] o patrocínio dos deputados $\gg{ }^{27}$. E o exemplo mais flagrante desta incapacidade do movimento regionalista ter-se-ia verificado, a exemplo de outros, no congresso de Coimbra: «na Assembleia coimbrã esteve o governo, estiveram os deputados dos diversos partidos e esteve o governador civil do distrito, o qual disse esperar que o poder central daria todo o apoio à obra do congresso. Além disso,

${ }^{25}$ Este Semanário de Castelo Branco era propriedade do Grupo Acção Regional, tinha como Director Manuel Pires Bento e principal redactor António Trindade. Vigorou entre 1924 e 1930. Além destes nomes, entre os fundadores do jornal encontrava-se também Jaime Lopes Dias, um dos grandes entusiastas do regionalismo Beirão. No Editorial do primeiro número (11 de Dezembro de 1924), apresenta-se aos leitores como um órgão pertencente ao Grupo Acção Regional, associação autónoma e independente dos partidos políticos e que visava «servir o país e, muito em especial, defender e promover os interesses peculiares da Província da Beira Baixa e da cidade de Castelo Branco. O grupo e o jornal tinham como principal função reorganizar a administração local, com base no município e nas regiões e criticavam a centralização política».

${ }^{26}$ Veja-se o Editorial do periódico Acção Regional, de 8 de Abril de 1926. Este mesmo artigo viria a ser incluído numa obra de Manuel Pires Bento, A Questão Municipal (subsídios para a reforma administrativa), publicada em 1928, com um prefácio de António Lino Neto, na altura Presidente do Centro Católico Português.

${ }^{27}$ Veja-se BENTO (1929: 8-9). 
o trabalho predominante dos congressistas traduziu-se em propostas para fazer pedidos ao governo - estradas, caminhos-de-ferro e semelhantes $\rangle^{28}$. Ora, nestes termos, «o regionalismo pelos congressos neutros e com a colaboração de todo o mundo [refere-se à presença do governo, deputados e governador civil] não pode ser senão uma coisa frouxa e efémera, e no pouco tempo que durar, uma pura ilusão, porque, oferecendo um exterior todo feito de harmonia e paz, tem, no fundo e como base, o mais completo desacordo de ideias e opiniões». Assim, os congressos em vez de «representarem momentos altos de uma luta pela descentralização, acabaram, paradoxalmente, por converter-se numa espécie de «regionalismo centralista, o regionalismo oficial, que em todo o país se tem feito até agora $»^{29}$.

Esta aparente contradição, subjacente ao movimento regionalista, manifestava-se, também, na própria cadeia de comando responsável pela organização dos congressos. Embora no discurso de alguns militantes regionalistas se verificasse uma clara identificação da centralização com a hegemonia (económica, social e cultural) exercida pela capital do país, não deixa de ser curioso que a ideia de organizar os congressos regionais tivesse partido precisamente do Grémio Beirão sediado em Lisboa ${ }^{30}$. Com efeito, como recordava Joaquim Rodrigues Lourenço - dirigente do Grémio Beirão -, a iniciativa de organizar o I Congresso Regional, em Viseu (1921), partiu dos beirões residentes na capital, começando com ele «a história do regionalismo organizado em Portugal ${ }^{31}$.

${ }^{28}$ De facto, através de uma análise detalhada das principais reivindicações feitas pelas Beiras nos diferentes congressos regionais, verifica-se que o destaque vai para a necessidade do desenvolvimento das redes rodoviárias, ferroviárias e portuárias. Detenhamo-nos apenas nos pedidos feitos ao governo no congresso de Coimbra, já que em todas as manifestações ulteriores se repetiram, sem que nenhuma delas, curiosamente, fosse solucionada: 1) construção de um Porto de Mar no Cabo Mondego e abertura de três canais marítimos, irradiando da enseada de Buarcos para Coimbra, Leiria e Aveiro; 2) Reabertura da antiga comunicação fluvial desde a foz do Dão até à Barra da Figueira; 3) abertura de dezenas de percursos ferroviários, com destaque para as ligações Gouveia-Arganil-Santa Comba Dão-Viseu-Espinho-Porto e Gouveia-Vila Franca das Naves-Régua-Porto; Viseu-Foz Tua; Régua a Vila Franca das Naves, por Lamego e Moimenta da Beira; de Viseu a Mangualde.

${ }^{29}$ Veja-se BENTO (1929: 9).

${ }^{30}$ Como curiosidade, diga-se que o jornal O Comércio de Viseu (16-05-1921), no rescaldo do I Congresso regional, apresentou como um erro o facto de a organização deste evento «não ter partido da periferia para o centro, constituindo só depois Lisboa um meio para o congresso ser levado a bom caminho e nunca a origem desse mesmo congresso».

${ }^{31}$ Veja-se, neste sentido, a tese apresentada por Joaquim Rodrigues Lourenço, «Organização Regional das Beiras», ao IV Congresso Regional das Beiras (1931: 300-307). 
Esta assumida paternidade dos beirões residentes em Lisboa desenvolveu-se ao ponto de, em vários congressos, se ter tentado criar uma «organização regional», sob a alçada do Grémio das Beiras (depois Casa das Beiras), que ficasse responsável, em coordenação com as comissões locais e distritais, pela realização anual dos congressos. Muito embora esta ideia nunca tivesse chegado a ser institucionalizada - a arquitectura desta pesada organização regionalista passava por criar uma rede que ia das freguesias e comissões de melhoramentos, às agremiações concelhias e conselhos distritais, terminando no Conselho Superior Regional, logicamente integrado no Grémio Beirão e com sede em Lisboa -, o peso do «regionalismo externo» foi sendo, com o passar do tempo, cada vez mais importante. Acentuou-se, aliás, à medida que avançava a institucionalização do Estado Novo e que perdia a sua vertente mais política e descentralizadora. Com efeito, ainda durante a Ditadura Militar, no congresso de Aveiro (1928), o Dr. José Andrade Saraiva - então vice-presidente do Conselho Regional do Grémio Beirão -, numa tese precisamente intitulada «Importância e razão de ser do regionalismo na época actual», não deixava grandes dúvidas sobre o caminho a percorrer no futuro: «o regionalismo deveria ser entendido como o desenvolvimento do amor pátrio, sem qualquer espírito de hostilidade contra a capital do país, que simboliza a unidade da nação e na qual todas as Províncias têm a sua parte» ${ }^{32}$.

\section{Natureza e contradições do movimento regionalista}

Como vimos, pouco tempo volvido sobre a implantação da República, começou a crescer no país um sentimento, sobretudo no extenso mundo rural, de alguma desconfiança sobre a capacidade do novo regime para resolver os crescentes problemas da Província. Porém, foi necessário esperar pela década de 1920 - quando, em Portugal, se viviam ainda as consequências da I Guerra e a "Nova República" se transformou, num abrir e fechar de olhos, em "República Velha" -, para que o movimento regionalista ganhasse maior visibilidade e poder reivindicativo.

O sentimento de revolta da Província, relativamente ao modo como os dirigentes republicanos faziam a mediação política entre Lisboa e as periferias, era o tema central das inúmeras teses apresentadas aos diversos congressos regionais das Beiras. Entre os vários exemplos possíveis, retenhamos a leitura desta situação feita pelo delegado da Covilhã no congresso regional de Coimbra (1922): «a política centralizadora do Terreiro do Paço caiu de norte a sul numa

${ }^{32}$ Veja-se III Congresso Regional das Beiras (1928: 48-56). 
irrespirável atmosfera de descrença. Os interesses dos partidos, as aspirações dos políticos, tantas vezes exclusivamente pessoais, não se harmonizam com as necessidades urgentes do país, e por via de regra fazem esquecer e abandonar a província que trabalha, pensa e produz. Fora os períodos eleitorais em que os pregadores da obra de ressurgimento nacional sobem aos tablados dos comícios pelo país fora, na ânsia duma candidatura, a política em Portugal gira no Terreiro do Paço ao Parlamento e concerta-se entre os gabinetes ministeriais e os directórios dos partidos. As grandes iniciativas, os projectos elevados de grandes empresas de fomento se não tiverem a escudá-las a protecção de um influente político, arrastam-se tempos infinitos atrás de mil formalidades burocráticas $\rangle^{33}$.

Em face desta total descrença nos mecanismos institucionais de protecção e de mediação política, não admira que as manifestações regionalistas, na medida em que visavam mudar a situação, fossem bem aceites pelas elites da Província. $\mathrm{O}$ regionalismo acabava por criar um sentimento de pertença e de unidade provincial que, pela primeira vez, transformava o descontentamento de toda uma Província, relativamente ao sistema instituído (parlamento, governo, partidos), numa forma de luta contra o centralismo e os interesses instalados no Terreiro do Paço. E assim, como salientava, em 1929, Manuel Pires Bento ${ }^{34}$, o regionalismo surgiu, por um lado, «com a crise do Parlamento e com o descrédito dos partidos [...] e, por outro, «brotou espontaneamente da própria crise política e deve ser interpretado como um movimento instintivo contra o absolutismo moderno, chamado centralização» ${ }^{35}$.

Não obstante a vontade expressa de alguns regionalistas em centrarem toda a sua luta no combate ao centralismo e na criação das condições políticas para uma maior autonomia e representatividade dos poderes periféricos, a verdade é que esta reacção da Província transportava consigo uma grande desconfiança do mundo rural, relativamente aos novos valores inerentes ao desenvolvimento do capitalismo. Com efeito, na luta contra a centralização também cabiam os discursos dos que recusavam os valores da modernidade e que, ao inevitável cosmopolitismo das cidades, contrapunham a superioridade moral

${ }^{33}$ Veja-se a tese apresentada pelo congressista Dr. Elmano Cunha e Costa (filho) no II Congresso Beirão (1922).

${ }^{34}$ Manuel Pires Bento, além de Advogado, foi Governador Civil de Beja (1898), Presidente da Câmara Municipal de Castelo Branco, durante a I República, e fundou, nesta mesma cidade, o semanário A Acção Regional (1924-1930), com o objectivo de desenvolver o espírito regionalista e municipalista. Além de uma participação activa no movimento regionalista beirão, foi autor da obra $A$ questão Municipal (subsídios para a reforma administrativa), com prefácio de Lino Neto (1928).

${ }^{35}$ Cf. BENTO (1929: 9-10). 
da mundividência do campo. A «crítica ao centralismo, ao uniformismo e ao cosmopolitismo moderno» eram, no entender do vice-presidente do conselho regional do Grémio Beirão, discursando no congresso regional de Aveiro (1928), as três ideias força do regionalismo. Era contra estes valores que o «verdadeiro regionalismo, baseado unicamente no amor ao lar, à região, à Pátria e à raça», se devia levantar ${ }^{36}$. Nesta perspectiva reactiva e conservadora foi também a tese apresentada ao mesmo congresso por Álvaro Viana de Lemos (professor da Escola Normal Primária de Coimbra) que, depois de defender a criação de escolas «com um carácter nitidamente regionalista, concluiu: «o bom regionalismo e a escola que o serve combatem o urbanismo, que é um mal, porque representa o triunfo da vida artificial das cidades contra a vida criadora e morigerada dos campos $\rangle^{37}$.

O movimento regionalista misturava, assim, partidários de uma descentralização administrativa que podia ir até à federação das regiões ${ }^{38}$; defensores de uma maior autonomia administrativa, dentro de um Estado unitário e simples motivações eruditas e sentimentais, centradas no amor à região natal, ao colorido das suas paisagens e a um conjunto de manifestações mais ou menos folclóricas. Das três correntes enunciadas - federalistas, descentralizadores e regionalistas pelo sentimento de amor à sua terra -, a primeira nunca teve condições para alguma vez se impor; a segunda, bastante activa no início, acabou por se render às prioridades políticas autoritárias e centralizadoras do Estado Novo; a terceira, no fundo a que arrastava gente, foi a que acabou por dar algum colorido ao regionalismo e ter mais efeitos no tempo.

Apesar das diferenças ideológicas das várias sensibilidades, havia, no entanto, no movimento regionalista um traço comum que, pelo seu carácter reactivo, unia praticamente todos os intervenientes: a sensação de abandono por parte do poder vigente e a recusa de um Estado jacobino e centralizado ${ }^{39}$. Porém, esta postura reactiva e de mão estendida aos favores do Poder Central, não agradava

${ }^{36}$ III Congresso Regional das Beiras (1928: 48-56).

${ }^{37}$ III Congresso Regional das Beiras (1928: 61-63).

${ }^{38}$ Recorde-se aqui, como confirmação de que os ideais federalistas estiveram presentes no movimento regional das Beiras, a tese apresentada por José Marques, «Organização Administrativa Provincial - Administração autónoma da Beira», ao I Congresso Beirão, realizado em Viseu, entre 9 e 14 de Junho de 1921. Sobre o ressurgimento, na década de 1920, dos ideais federalistas caídos no esquecimento, por parte dos republicanos, após a aprovação da constituição de 1911 que, como é sabido, consagrou a República unitária, veja-se LEAL (2001).

${ }^{39}$ Esta capacidade do movimento regionalista unir pela negativa, em determinado momento, várias sensibilidades políticas, não foi apenas uma característica portuguesa, o mesmo se passou noutros países europeus, particularmente Espanha e França. Veja-se, neste sentido, TORREJON (1973: 378-380); VIGIER (1977: 161-175); LOVIE (1977: 430-494); MAYEUR (1977: 445-460). 
aos líderes mais esclarecidos e empenhados politicamente. Estavam neste grupo os integralistas, onde pontificava o grupo ligado ao Acção Regional de Castelo Branco. Num dos seus trabalhos, especialmente elaborado para o IV Congresso Beirão (1929) ${ }^{40}$, Manuel Pires Bento lamentava-se precisamente pelo facto de o regionalismo, em Portugal, ser um movimento sem uma orientação política definida. Em apoio da sua tese, recordava o congresso anterior realizado em Coimbra, onde, não obstante estar presente a elite política, académica e religiosa, todos foram unânimes no reconhecimento de que o regionalismo «traduzia um conceito vago e impreciso $»^{41}$. Foi, aliás, esta ambiguidade do conceito, lembra, que teria levado o então reitor da Universidade de Coimbra (Dr. António Luís Gomes) a aprovar uma proposta para que fosse nomeada uma comissão para definir o regionalismo que se desenvolvia na Beira ${ }^{42}$. Ora, assim sendo, a conclusão dos integralistas só podia ser a seguinte: «só há necessidade de definir o que ainda não está definido» ${ }^{43}$.

Apesar da dificuldade em definir os contornos de um movimento que albergava sensibilidades políticas contraditórias, Manuel Pires Bento não deixou de, numa das suas obras ${ }^{44}$, tentar clarificar as águas no interior do regionalismo, apontando-lhe quatro grandes sensibilidades: o regionalismo contra os partidos; o regionalismo político; o regionalismo autonomista e o regionalismo externo. O regionalismo contra os partidos, era, na sua essência, conservador e visava uma alternativa ao demo-liberalismo. Esta sensibilidade deu ao regionalismo, desde o início, uma coloração política mais radical, não só porque pretendia uma reforma administrativa identificada com o passado anterior ao Liberalismo, mas porque pretendia uma outra organização do Estado, sem partidos, substituindo a administração dos políticos pelas corporações ${ }^{45}$. O regionalismo político, para seguirmos a taxinomia do autor citado, era mais ambíguo

${ }^{40}$ BENTO (1929).

${ }^{41}$ BENTO (1929: 4).

${ }^{42}$ Como tantas vezes acontece, o trabalho desta comissão não viria ser conhecido.

${ }^{43}$ BENTO (1929:4).

${ }^{44}$ BENTO (1928).

45 Atente-se, por exemplo, na interpretação que Hipólito Raposo (1885-1953), integralista da 1.' geração, fazia do regionalismo, no número especial do jornal Acção Regional (1929), totalmente dedicado ao $I V$ congresso regional das Beiras: «a vitalidade e a justiça das aspirações regionalistas estão oferecendo a quem governa ou vier a governar preciosas indicações para a reforma orgânica do Estado. [...] Não pode o regionalista escravizar-se a partidos de qualquer tendência, um qualquer regime; não se pode ao mesmo tempo ser regionalista, promotor da descentralização nas leis e no governo e ter praça assente num partido, cuja actividade, como condição da própria vida, não pode deixar de concluir na concentração do poder». Veja-se Acção Regional, de 16 de Junho de 1929. 
ideologicamente, cabendo nele todos os que, independentemente da cor política, apelavam a uma descentralização efectiva com criação de regiões, dentro de um Estado Unitário, federalista e municipalista. Cabia neste regionalismo político, a vertente autonomista tão cara a Manuel Pires Bento e que por ela se bateu nos congressos regionais e no quadro do Grupo Acção Regional, sendo assim apresentada pelo próprio: «há duas ordens de interesses ou necessidades públicas: os interesses gerais e os interesses locais, as necessidades gerais da nação e as necessidades peculiares de cada região ou localidade. Os interesses regionais são característicos, diferentes e, em certo sentido, opostos ao Estado. Importa, pois, que existam instituições, organismos, forças próprias, para procurar satisfação às necessidades locais. [...] O nosso regionalismo, que bem se pode chamar municipalismo, é descentralizador e inspira-se no princípio tradicional na vida portuguesa - de que às localidades pertence o direito de se governarem a si próprias, cumprindo-lhes apenas e sem prejuízo da sua autonomia local manter, puro e íntegro, o sentimento da unidade nacional, os laços de coesão que fazem de Portugal um Estado perfeitamente unido» ${ }^{46}$. Resta-nos, por fim, o regionalismo externo. Como o próprio autor que temos vindo a citar o define, tinha origem nos que fugiram à miséria nos campos e migraram para a capital. Aqui, associados nos respectivos grémios regionais, tentavam reflectir na melhor forma de ajudar as suas terras de origem. Este regionalismo caracterizava-se, no fundo, por se ter um interesse particular pelo torrão natal. Agregava todos os que, independentemente dos seus posicionamentos políticos e partidários, apreciavam as belezas e curiosidades locais e que, além de mais, pugnavam pela defesa da cultura e identidade das suas regiões. Esta forma de regionalismo «inspirava, como é natural, sentimentos nobilíssimos». Em especial, pelo facto de ser o resultado do esforço dos que viviam fora e que, apesar disso, procuravam melhorar e engrandecer as terras de onde tinham partido. «A intenção era delicadíssima, os fins elevadíssimos; os meios de actuar é que não mereciam o aplauso dos que, além do amor à terra natal, queriam ver «a região a governar-se directamente». E, sobretudo, porque esta concepção de regionalismo, menos empenhada politicamente, acabou por enfraquecer as posições dos que viram no movimento regionalista uma oportunidade única para o desenvolvimento de uma «acção local unificada» e que sempre pretenderam ver «as instituições regionalistas domiciliadas na região» ${ }^{47}$.

\footnotetext{
${ }^{46}$ BENTO (1928: 140-146).

${ }^{47}$ BENTO (1928: 143-146).
} 
Em face das contradições ideológicas existentes no seu seio e tendo em conta o peso que o regionalismo externo sempre teve nos congressos regionais, talvez não surpreenda a evolução posterior deste movimento, em especial a sua identificação com a matriz conservadora e autoritária do Estado Novo. O ponto de viragem, neste sentido, dá-se, de facto, com o ambiente político criado pelo Salazarismo, que sossegou as correntes mais conservadoras e deu mais segurança às elites da Província.

A aparente indefinição ideológica e, por vezes, contraditória do movimento regionalista não foi uma especificidade portuguesa. Isto mesmo aconteceu em França, onde, não obstante nos finais do século XIX a palavra regionalismo já ter entrado no uso corrente, continuavam nas primeiras décadas de Novecentos a não ser muito claros os seus contornos ideológicos ${ }^{48}$. No entanto, o conteúdo reactivo e conservador do regionalismo foi sempre uma constante, ainda que, como se entende, se acentuasse depois da queda da I República e durante o Estado Novo. Aliás, este rumo ficou bem expresso no principal semanário de Viseu, quando felicitava a ditadura Militar por ter supostamente acabado com «o caciquismo eleitoral e as manifestações anárquicas de reclamação», podendo agora o regionalismo atenuar «os dissídios da população, tendendo a apagar as paixões políticas e a conciliar elementos de valor nas localidades $\rangle^{49}$.

Assim, ao contrário do que por vezes se pensa, a Ditadura Militar e o Estado Novo não precisaram de fazer muito - na verdade, se excluirmos a divisão administrativa do território em Províncias, nada do que foi reclamado nos congressos regionais das Beiras (maior descentralização, vias-férreas, portos marítimos, etc.) foi satisfeito -, para que o movimento regionalista lhes caísse nos braços. Os principais líderes locais do movimento regionalista e os seus representantes na Casa das Beiras, em Lisboa, depressa se identificaram (se não estavam já identificados) com a nova ordem imposta. Por saberem isso, os vários governos da Ditadura Militar nunca recusaram o apoio à organização dos congressos nas Beiras - entre 1928 e 1932 realizaram-se três, enquanto que, durante I República, apenas dois -, aproveitando estas manifestações, até pelas críticas que aqui se faziam aos governos anteriores, para garantirem uma maior adesão popular à Ditadura. Só assim se justifica o empenho demonstrado pelo governador civil de Coimbra, na organização do congresso regional da Figueira da Foz, ao dirigir-se ao seu homólogo de Viseu, em 19 de Setembro de 1932: «tendo chegado ao meu conhecimento que elementos desafectos à ditadura pretendem prejudicar a imponência que deve revestir o próximo congresso

\footnotetext{
${ }^{48}$ A este respeito, TORREJON (1973: 281-282); VIGIER (1977: 160-175).

49 O Comércio de Viseu, de 22 de Janeiro de 1928.
} 
Beirão [...], rogo a V. Excelência se digne envidar os seus dedicados esforços para que os municípios desse distrito se façam representar na máxima força no referido congresso, onde serão tratados todos os assuntos de maior valorização regional e entre estes a crise vinícola $\rangle^{50}$.

Mas se, no período da Ditadura Militar, são já evidentes os sinais que identificam as elites mais activas do movimento com a nova situação política, a leitura do Boletim da Casa das Beiras e a preparação dos VI e VII congressos regionais - realizados respectivamente nas cidades de Coimbra (1936) e Viseu (1940) - apontam já para uma revisão da própria origem e história do regionalismo e para uma subordinação clara deste aos objectivos políticos e ideológicos do regime ${ }^{51}$. Na edição n. ${ }^{\circ} 1$ do Boletim da Casa das Beiras (1935), Domingos Pepulin, na sua qualidade de director, escreveu: «na sua raiz, é o regionalismo a primeira expressão, a mais simples e basilar do nacionalismo. O regionalismo não dispõe de autoridade, mas defende, pelo amor à tradição e ao património moral e local, a própria nação, contra a desordem, confusão e desmandos de dentro e contra a descoordenação de interesses e aspirações locais; procura disciplinar os espíritos numa doutrina de abnegação pelo bem comum da nossa região: é a primeira cidadela de combate contra as ofensivas e devastações do Internacionalismo ${ }^{52}$.

Cinco anos mais tarde (1941), o discurso e a ideologia não se tinham alterado e tentava-se já uma simplificação revisora do que representou o regionalismo, acentuando-lhe a sua vertente mais conservadora e, por maioria de razão, a que mais se identificava com os interesses políticos do salazarismo: «o regionalismo português nasceu espontaneamente do próprio instinto de defesa dos valores morais em perigo, numa pátria sacudida por um prolongado referver de egoísmos e paixões que não davam quartel às aspirações de paz, regeneração e progresso do povo português. [...] Só integrados neste belo movimento regional é possível o amor, a assistência, o auxílio a cada desvalido provincial e a união, a batalha patriótica pelo despertar em cada português disperso pelo mundo [...]

${ }^{50}$ Veja-se ADV, Fundo do Governo Civil de Viseu, Correspondência Recebida (carta de 19 de Setembro de 1932), caixa n. ${ }^{\circ} 2605$.

${ }^{51}$ Em Maio de 1936, numa reunião, em Viseu, para preparar o VI Congresso Regional, a realizar em Coimbra entre os dias 30-06-1936 e 03-07-1936, o Dr. Afonso de Melo, como Presidente do Conselho Regional da Casa das Beiras, afirmou a um jornal local: «a obra dos congressos deve integrar-se no espírito nacionalista, ou de interesse nacional colectivo que inspira a acção orientadora do Poder Central. Que isso mesmo dava «à obra dos congressos regionais uma grande oportunidade» porque, diz, «estamos num período de renovação». Veja-se Jornal da Beira, de 21 de Maio de 1936.

${ }^{52}$ Boletim da Casa das Beiras, n. ${ }^{\circ}$, de Abril de 1935, p. 10. 
da chama ardente da família e do lar de origem, chamando-o assim à tradição regionalista, a cerrar fileiras em volta do velho plinto provincial, o suporte étnico e tradicionalista da estrutura da nação ${ }^{53}$. E, para que não ficassem dúvidas sobre as intenções dos representantes do regionalismo beirão para com o Estado e o governo, escrevia-se ainda no órgão oficial da Casa das Beiras: «julgamos fazer política superior do próprio Estado; assim julgamos poderem disciplinar-se as forças morais livres e até as políticas locais, sob o guião do regionalismo provincial, como a primeira e grande força desinteressada da própria Nação» ${ }^{54}$. Mais adiante, acrescentava-se: «o regionalismo poderia bem ser em certos aspectos da ordem política o que a religião é na ordem moral» ${ }^{55}$.

Face a esta evolução do movimento regionalista - sobretudo quando já eram conhecidas as práticas e as intenções centralizadoras do Estado $\mathrm{Novo}^{56}$-, poderia perguntar-se: o que aconteceu aos regionalistas que, durante a I República e mesmo no período da Ditadura Militar, não se cansaram de criticar os malefícios da centralização política? A resposta mais fácil, para explicar o silêncio que se seguiu, seria dizer que tudo se apagou com a falta de liberdade de expressão e de reunião. Contudo, as perseguições, a polícia política e a censura tiveram, sem dúvida, influência naquilo que, apesar de tudo, foi uma inflexão reivindicativa importante do movimento regionalista, mas não explicam tudo, nem sequer o essencial. Como fomos defendendo, o movimento regionalista foi sempre, na sua essência - mesmo quando defendia ideias avançadas para a administração do poder local - conservador ${ }^{57}$. E, sobretudo, mostrou-se sempre receoso da hegemonia (económica, social e ideológica) que a cidade progressivamente ia tendo sobre o mundo rural. Ora, a matriz rural, conservadora e autoritária do Estado Novo - que, no discurso, enaltecia a vida no campo e criticava o cosmopolitismo e, na prática, tentava harmonizar uma economia pré-moderna com a inevitável modernização - acabou por responder ao que de mais importante e profundo mobilizava a maioria das elites regionalistas. Não queremos com isto dizer que não houvesse excepções, mesmo no seio dos que sempre apoiaram o Estado Novo. Mas, para estes, o combate ao adversário da situação e a necessidade da unidade nacional acabaram por ser

${ }^{53}$ Boletim da Casa das Beiras, n. ${ }^{\circ}$ 24, de Dezembro de 1941, p. 3.

${ }^{54}$ Idem, p. 11.

55 Ibidem.

${ }^{56}$ Tenha-se em consideração que a arquitectura orgânica que o Estado Novo construiu, na década de trinta, caracterizou-se por um controlo quase total, por parte da Administração Central, dos diferentes poderes periféricos.

${ }^{57}$ Cf. CATROGA (2005). 
argumentos mais do que suficientes para que deixassem de reivindicar uma maior descentralização ${ }^{58}$.

\section{Conclusão}

O regionalismo inscreve-se numa reacção profunda da Província contra as transformações económicas, políticas e sociais (internas e externas) ligadas à denominada modernidade. O movimento regionalista assume-se, desde o início, não obstante as ambiguidades e contradições políticas, claramente contra aquilo que consideravam ser os malefícios da modernidade, sobretudo por colocarem em causa a tradicional mundividência e, ao mesmo tempo, por imporem um novo paradigma de relações sociais que, progressivamente, ia apagando as velhas referências simbólicas e identitárias. Estas mudanças, mesmo que aparentemente lentas em Portugal, foram sentidas de forma muito especial no mundo rural, onde os antigos equilíbrios sociais se romperam, sem que os vários poderes (central e periféricos) e a crise do demoliberalismo criassem novos mecanismos para os poderem debelar.

A análise que fizemos da vasta documentação directa e/ou indirectamente ligada aos congressos regionais - actas dos congressos, teses e publicações individuais de congressistas, notícias e reacções nos jornais nacionais e regionais, informações trocadas entre os poderes central e periféricos - permite-nos concluir que o movimento regionalista, depois da queda da I República e durante o Estado Novo, acentuou a sua matriz mais tradicionalista e conservadora. A vertente mais activa do regionalismo da década de 1920, contra a centralização político-administrativa e o abandono por parte do poder central, como que se apagou, acabando este movimento por ser incorporado na defesa ideológica das virtudes do campo, tão ao gosto do folclore ruralista e pré-moderno do Salazarismo. Esta evolução, aliás, ajuda a explicar muitas das contradições políticas, sociais e ideológicas que estiveram, desde o início, presentes neste movimento ${ }^{59}$.

${ }^{58}$ Retenha-se aqui, como exemplo de que nem todos os apoiantes do Estado Novo se calaram, o caso de Alexandre de Lucena e Vale - era então Presidente da Junta de Província da Beira Alta e Director da revista Beira Alta - que, em 1944, criticou abertamente o carácter centralizador do Estado Novo e, sobretudo, todos aqueles que, «por espírito de disciplina e em homenagem aos altos propósitos de regeneração e ascensão nacionais [...] se calavam». Veja-se VALE (1944: 190-197).

${ }^{59}$ Refira-se que estas contradições políticas do movimento regionalista não são exclusivas do caso português; o cariz descentralizador do regionalismo das primeiras décadas do século XX vai ser solicitado tanto pelos sectores conservadores e de direita, como por partidos mais à esquerda. A direita pretende voltar à descentralização anterior à revolução francesa, de privilégios localistas; a esquerda, por sua vez, reivindica uma descentralização federalista e mesmo, como acontecia 
Importa, por isso, deixar bem claro que o movimento regionalista aqui analisado pouco tem que ver com as propostas de desenvolvimento regional da segunda metade do século XX. O regionalismo moderno tem subjacente, desde logo, uma consciência mais apurada dos desequilíbrios económicos entre espaços e, em termos teóricos e práticos, desvaloriza os aspectos históricos, culturais e político-administrativos, para enfatizar aos aspectos de planeamento económico-administrativos. Nada mais errado, portanto, do que tentar ver neste regionalismo da $1 .{ }^{\mathrm{a}}$ metade do século XX uma etapa ou um prenúncio do conceito recente de desenvolvimento regional. Aliás, em Portugal, as primeiras iniciativas de desenvolvimento regional, enquanto instrumento de uma política económica, surgiram apenas, de forma mais ou menos envergonhada, nos finais da década de 1960, princípios da década de 1970, na sequência do III Plano de Fomento (1968-1973).

\section{Referências Bibliográficas}

AA.VV. (1977), Régions et Régionalisme en France du XVIII ème siécle à nos Jours, Strasbourg, PUF.

AMARO, António Rafael (2006), Economia e Desenvolvimento na Beira Alta: dos Finais da Monarquia à II Guerra Mundial (1890-1939), Lisboa, Universidade Católica Editora.

BENTO, Manuel Pires (1928), A Questão Municipal (Subsidio para a reforma administrativa), Castelo Branco, s.ed.

BENTO, Manuel Pires (1929), Da Acção Regional ao IV Congresso Beirão, Vila Nova de Famalicão, Minerva.

CATROGA, Fernando (2005), «Geografia e política: a querela da divisão provincial na I República e no Estado Novo», FONSECA, F. Taveira da (coord.), O Poder Local em Tempo de Globalização: uma história e um futuro, Coimbra, Imprensa da Universidade.

FONSECA, F. Taveira da (coord.), O Poder Local em Tempo de Globalização: uma história e um futuro, Coimbra, Imprensa da Universidade.

GIRÃO, Aristides de Amorim (1933), Esbôço duma Carta Regional de Portugal, $2^{\circ}$ ed., Coimbra, Imprensa da Universidade.

LEAL(2001), Ernesto Castro (dir.), O Federalismo Europeu. História, Política, Utopia, Lisboa, Edições Colibri.

em Espanha, a autonomia das regiões. Veja-se, neste sentido, TORREJON (1973); MAYEUR (1977); LOVIE (1977); VIGIER (1977); SIMÓN e VALCÁRCEL (1996). 
LOVIE, Jacques (1977), «Essai sur le régionalisme savoyard», in Régions et régionalisme en France du XVIII ${ }^{e}$ siècle à nos Jours», Strasbourg, Presses Universitaires de France.

MAYEUR, Jean Marie (1977), «Démocratie Chrétienne et Régionalisme», in Régions et régionalisme en France du XVIII ${ }^{e}$ siècle à nos Jours», Strasbourg, Presses Universitaires de France.

MENDES, José M. de Oliveira (1996), «O regionalismo como construção identitária. O caso dos Açores», Revista Crítica de Ciências Sociais, nº 45, p. 127-142.

NGUYEN, Victor (1977), «Aperçois sur la conscience d'Oc autour des annés 1900 (vers 1890-vers 1914, in AA.VV. (1977), Régions et Régionalisme en France du XVIII ème siécle à nos Jours, Strasbourg, PUF.

SIMÓN, A. Garcia; VALCÁRCEL, J. Ortega (dir.) (1996), «Castilla y León. De la transición democrática a la autonomia», História de uma Cultura, Castilla Y León, Vol. IV, Junta de Castilla Y León, Consejeria de Educación Y Cultura.

TORREJON, Amparo Rubiales (1973), La region: historia y actualidad, Sevilla, Instituto Garcia Oviedo, Universidad de Sevilla.

VALE, Alexandre de Lucena e (1944), «À margem do Congresso: autarquias locais», Beira Alta, vol. III (fasc. II-2. ${ }^{\circ}$ trimestre), Viseu.

VENTURA, António (2001), «Centralismo e regionalismo: movimentos regionalistas no Alentejo durante a I República», LEAL(2001), Ernesto Castro (dir.), O Federalismo Europeu. História, Política, Utopia, Lisboa, Edições Colibri.

VIGIER, Philippe (1977), «Régions et Régionalisme en France au XIX siècle», in Régions et régionalisme en France du XVIII siècle à nos Jours», Strasbourg, Presses Universitaires de France. 